\title{
Anatomical Variations of the Bifid Mandibular Canal on Panoramic Radiographs in Citizens from Zagreb, Croatia
}

\section{Anatomske varijacije dvostrukoga mandibularnog kanala na ortopantomogramima stanovnika Zagreba}

\author{
${ }^{1}$ Department of Maxillofacial and Oral Surgery, University Hospital Dubrava, University of Zagreb School of Dental Medicine, Zagreb, Croatia \\ Klinika za kirurgiju lica, čeljusti i usta Kliničke bolnice Dubrava, Stomatološki fakultet Sveučilišta u Zagrebu, Hrvatska \\ ${ }^{2}$ Faculty of Medicine University of Rijeka, Rijeka, Croatia \\ Medicinski fakultet Sveučilišta u Rijeci, Hrvatska \\ 3 University of Zagreb School of Medicine, Zagreb, Croatia \\ Medicinski fakultet Sveučilišta u Zagrebu, Hrvatska \\ ${ }^{4}$ Department of Maxillofacial and Oral Surgery, University Hospital Dubrava, University of Zagreb School of Medicine, Zagreb, Croatia \\ Klinika za kirurgiju lica, čeljusti i usta Kliničke bolnice Dubrava, Medicinski fakultet Sveučilišta u Zagrebu Hrvatska
}

\begin{abstract}
The bifid mandibular canal (BMC) is an anatomical variation with reported prevalence ranging from 0.08 to $65 \%$. Identifying anatomical variations of mandibular canal is very important in order to prevent possible complications during oral surgical and other dental procedures. Objectives: The aim of this study was to determine the prevalence and to classify the morphology of BMCs using digital panoramic radiographs. Material and methods: A retrospective study was conducted that included 1008 digital panoramic radiographs ( 412 female and 596 male) used to identify the type of BMC. Panoramic radiographs were analyzed by three oral surgeons and one dentist, and BMCs were classified into six different types, 4 types according to Langlais et al. (types 1-4), and two new types (types 5 and 6) described by authors. Results: The prevalence of BMC was $4.66 \%(n=47)$, with no significant differences in gender between BMC types $\left(P=0.947 ; \chi^{2}=0.74\right)$. The prevalence of type $1 \mathrm{BMC}$ was 0.79 $\%(n=8)$, type $22.08 \%(n=21)$, type $30.30 \%(n=3)$, type $40 \%(n=0)$, type $50.89 \%(n=9)$ and type $60.60 \%(n=6)$. Conclusion: This study revealed a relatively high prevalence of BMCs among Zagreb citizens. Furthermore, two new types of BMCs were described. These results stress the importance of a careful and thorough radiographic analysis prior to each invasive procedure in the mandible.
\end{abstract}

Received: July 16, 2021

Accepted: September 1, 2021

Address for correspondence Ivan Salarić

University of Zagreb

School of Dental Medicine

Department of Maxillofacial and Oral

Surgery

University Hospital Dubrava

Avenija G. Šuška 6, 10000 Zagreb,

Croatia.

salaric@sfzg.hr

MeSH terms: Mandible; Anatomic Variation; Oral Surgery

Author keywords: Radiography; Panoramic; Anatomic Variation; Mandible; Mandibular Nerve; Mandibular Canal; Bifid Mandibular Canal

\section{Introduction}

In 1973, Patterson and Funke (1), and Kiersch and Jordan (2) first used the term bifid mandibular canal (BMC). Until then, the mandibular canal had been described as a single structure, with the possibility of multiple smaller branches along the main trunk. Furthermore, it has been mentioned that some of these branches could be large enough to form a BMC or trifid mandibular canals (TMCs) (3).

The bifid mandibular canal is an anatomical variation located in the body or ramus of the mandible, where the mandibular canal is divided into two branches. The mandibular nerve is divided into the anterior branch, containing motor branches, and one sensitive buccal nerve, and the posterior branch containing sensitive branches. The mandibular canal enters the mandible and extends bilaterally from mandibu-
Uvod

Godine 1973. Patterson i Funke (1) te Kiersch i Jordan (2) prvi su upotrijebili naziv dvostruki mandibularni kanal (DMK). Do tada se najčešće ta pojava opisivala kao jedinstvena struktura s potencijalnim malim ograncima uzduž glavnoga debla živca. Nadalje, navodi se da pojedine grane mogu biti dovoljno velike da oblikuju DMK i trostruki mandibularni kanal (TMK) (3).

Dvostruki mandibularni kanal anatomska je varijacija smještena u tijelu ili uzlaznom kraku donje čeljusti gdje se mandibularni kanal dijeli u dvije grane. Mandibularni živac podijeljen je na prednju granu koja sadržava motoričke ogranke i jedan senzorički živac (bukalni) i stražnju granu sa senzoričkim ograncima. Mandibularni kanal počinje mandibularnim otvorom i proteže se do mentalnoga otvora te za- 
lar foramen to the mental foramen and it ends as an incisive nerve. In radiographs, the mandibular canal appears as a dark, linear shadow between two radiopaque thin borders. It contains a bundle with several important structures: the inferior alveolar nerve (IAN), artery and vein (4). In the development of the mandibular canal, Meckel's cartilage forms the skeleton of the first branchial arch (mandibular). The bilateral bodies of mandible evolve from ossification centers located lateral to Meckel's cartilage. The inferior alveolar nerve has been assumed significant in inducing osteogenesis. A study by Chavez-Lomeli et al. (5) on 302 hemimandibles from the second half of the prenatal period aimed to investigate the development of the mandibular canal. First, the canal appears in the area of the primary incisors, afterwards in the area of primary molars and finally in the permanent molars region. The authors concluded that the mandibular canal develops from at least three independent canals. Further development commonly results in fusion of the originally distinct canals, but fusion failure can result in a BMC or TMC (6).

The prevalence of the BMC has been reported in many studies, ranging from $0.08 \%$ to $8.3 \%$ when it was assessed using panoramic radiographs, and ranging from 10$65 \%$ when they were evaluated using cone-beam computed tomography (CBCT) (7-10). A panoramic radiograph is one of the most used diagnostic tools in dentistry. To a clinician, a panoramic image provides information on the location of mental foramen, IAN and other important anatomical structures in the maxilla and mandible (11).

Various types of BMCs have been described and classified according to anatomical location and based on panoramic radiographs or CBCTs. There are several classifications of BMC in the literature in the past 50 years: BMC classification by Nortje et al. (1977), Langlais et al. (1985), Kieser et al. (2005), Naitoh et al. (2009), Kuribayashi et al (2010), Rashid et al (2011) and Andrade et al. (2015) $(3,4,7,10,12-14)$. All these classifications divide BMCs into four different types, except the classification by Rashid et al. (13) which divides them into three types. The most commonly used BMC classification in the literature is the one by Langlais et al. (10) from 1985 (3, 4, 15). In the Langlais et al. classification, type 1 (Figure 1) refers to a unilateral or bilateral bifurcation extending to the region of the third molar or surrounding area. Type 2 (Figure 2) refers to a unilateral or bilateral bifurcation extending along the main canal and then merging in the mandibular ramus or body. Type 3 (Figure 3) refers to a combination of type 1 and 2, and type 4 (Figure 4) refers to $\mathrm{BMC}$ originating from two distinct mandibular apertures which afterwards merge into a single, broad mandibular canal (10).

It is needless to stress the importance of preoperative determining of the course and position of the mandibular canal and identifying possible anatomical variations. After 1973, when the first case was reported, clinicians and researchers began to pay more attention to the potential existence of BMC (7). Third molar extraction, dental implant placement, enucleations of pathologies, peri-apical surgery and sagittal ramus split osteotomy are just some of the procedures in which determining the position of the mandibular canal is vršava kao incizivni živac. Radiološki se mandibularni kanal prikazuje kao tamna linearna sjena između dviju tankih radioopaktnih linija, a sadržava snop s važnim strukturama donjim alveolarnim živcem, arterijom i venom (4). U razvoju mandibularnoga kanala Meckelova hrskavica tvori osnovu prvoga škržnoga luka (mandibulani luk). Bilateralna tijela mandibule stvaraju se iz osifikacijskih centara smještenih lateralno od Meckelove hrskavice i pretpostavlja se da je donji alveolarni živac važan u induciranju osteogeneze. Istraživanje koje su proveli Chavez-Lomeli i suradnici (5) na 302 hemimandibule iz druge polovine prenatalnoga razvoja imalo je kao cilj istražiti razvoj mandibularnoga kanala. Kanal se najprije pojavljuje u regiji mliječnih sjekutića, zatim u regiji mliječnih kutnjaka i na kraju u području trajnih kutnjaka. Autori su zaključili da mandibularni kanal nastaje od najmanje triju zasebnih kanala. Daljnji razvoj najčešće rezultira spajanjem u jedan zajednički kanal, ali neuspješno spajanje može rezultirati nastajanjem DMK-a ili TMK-a (6).

U mnogim istraživanjima ortopantomogramskih snimki ustanovljena je učestalost DMK-a od 0,08 do 8,3 \% te od 10 do $65 \%$ kada su analizirane Cone Beam kompjutorizirane tomografije (CBCT) $(7-10)$. Ortopantomogramske snimke jedan su od najkorisnijih dijagnostickih alata u dentalnoj medicini jer kliničaru daju informacije o lokalizaciji mentalnoga otvora, donjega alveolarnoga živca i drugih važnih struktura u donjoj i gornjoj čeljusti (11).

Različiti tipovi DMK-a opisani su i klasificirani ovisno o anatomskoj lokalizaciji utvrđenoj na panoramskim i CBCT snimkama. U literaturi je posljednjih 50 godina opisano nekoliko klasifikacija DMK-a - prema Nortjeu i suradnicima (1977.), Langlaisu i suradnicima (1985.), Kieseru i suradnicima (2005.), Naitohu i suradnicima (2009.), Kuribayashiju i suradincima (2010.), Rashidu i suradnicima (2011.) i Andradeu i suradnicima (2015.) (3, 4, 7, 10, 12 - 14). Sve navedene klasifikacije dijele DMK na četiri različita tipa, osim one Rashida i suradnika (13) koji je dijeli na tri tipa. Najčešće korištena klasifikacija u literaturi jest klasifikacija prema Langlaisu i suradnicima (10) iz 1985. godine $(3,4,15)$. U njihovoj klasifikaciji tip 1 (slika 1.) je unilateralni ili bilateralni kanal koji se dijeli na dva odvojena kanala od kojih jedan završava u regiji trećeg kutnjaka. Tip 2 (slika 2.) odnosi se na kanal (unilateralno ili bilateralno) koji se razdvaja u dva odvojena kanala, zatim se kanali u uzlaznom kraku ili tijelu donje čeljusti spajaju u jedan koji završava mentalnim otvorom. Tip 3 (slika 3.) kombinaciju je tipova 1 i 2 , a tip 4 (slika 4.) odnosi se unilateralno ili bilateralno na DMK-u koji počinje $s$ dva zasebna mandibularna otvora koji se zatim spajaju u jedinstveni, široki mandibularni kanal (10).

Nije potrebno isticati važnost prijeoperacijskoga određivanja tijeka i položaja mandibularnoga kanala i utvrđivanja potencijalne anatomske varijacije. Nakon što je 1973. godine objavljen prvi prikaz pacijenta s DMK-om, kliničari i znanstvenici počeli su mnogo više pozornosti posvećivati potencijalnom postojanju dvostrukoga mandibularnoga kanala (7). Ekstrakcija i alveotomija umnjaka, ugradnja dentalnih implantata, enukleacija patoloških tvorbi, periapikalni kirurški zahvati i sagitalna osteotomija kraka mandibule, samo su neki od zahvata kada je iznimno važno odrediti položaj man- 

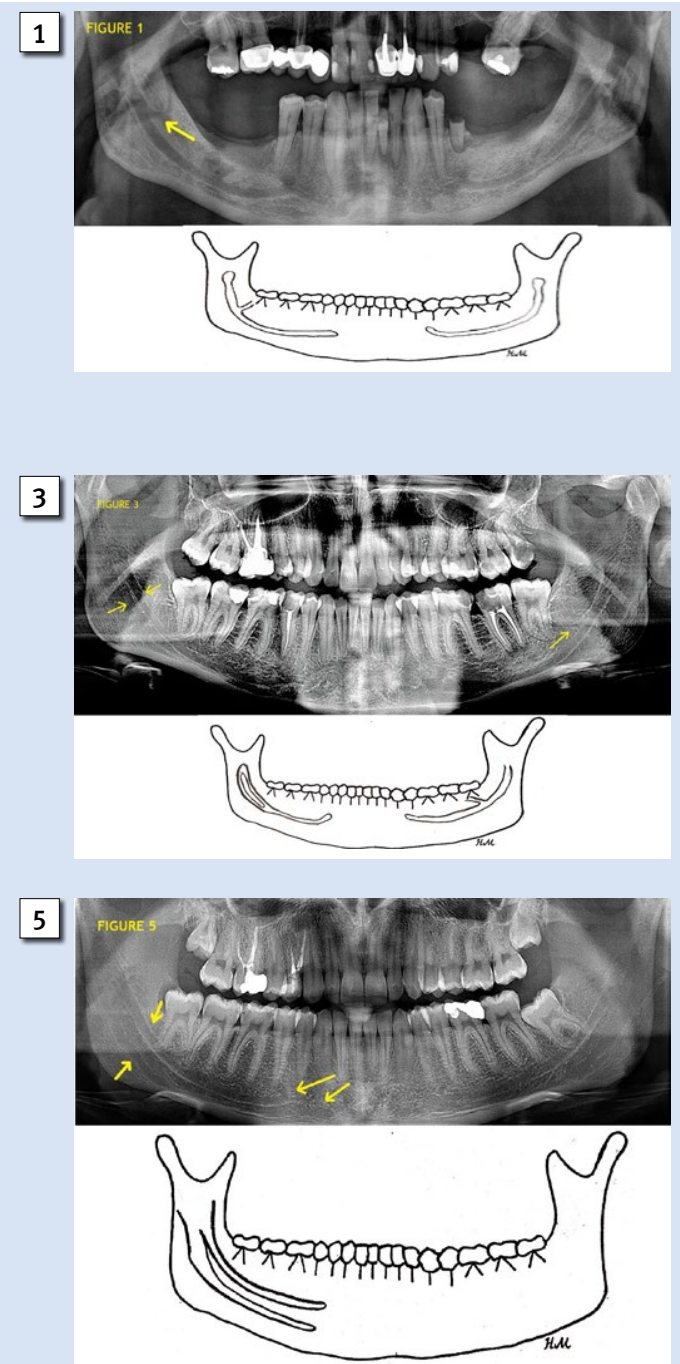

Figure 1 Type 1 bifid mandibular canal according to Langlais et al.

Slika 1. Tip 1 dvostrukoga mandibularnoga kanala prema Langlaisu i sur.

Figure 2 Type 2 bifid mandibular canal according to Langlais et al. Slika 2. Tip 2 dvostrukoga mandibularnoga kanala prema Langlaisu i sur.

Figure 3 Type 3 bifid mandibular canal according to Langlais et al.

Slika 3. Tip 3 dvostrukoga mandibularnoga kanala prema Langlaisu i sur.
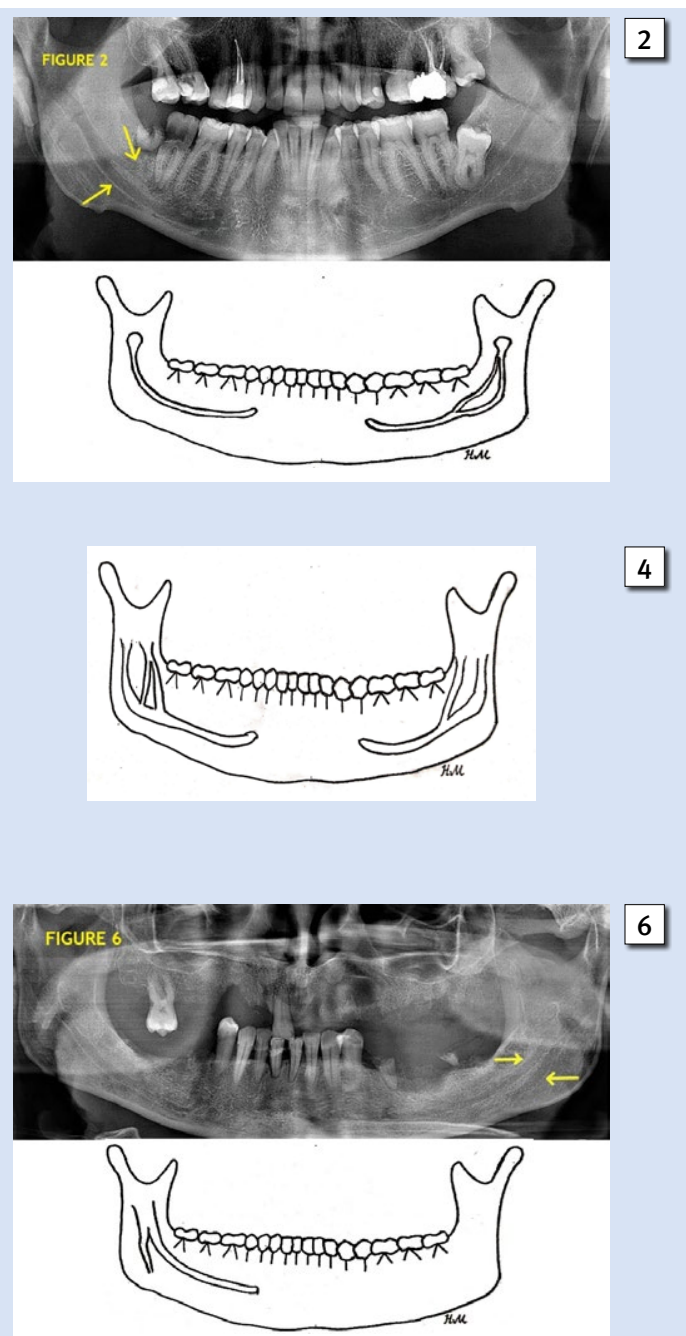

Figure 4 Type 4 bifid mandibular canal according to Langlais et al.

Slika 4. Tip 4 dvostrukoga mandibularnoga kanala prema Langlaisu i sur.

Figure 5 Bifid mandibular canal type 5

Slika 5. Dvostruki mandibularni kanal tip 5

Figure 6 Bifid mandibular canal type 6

Slika 6. Dvostruki mandibularni kanal tip 6 of the utmost importance (16). Furthermore, BMCs are often associated with the failure to obtain an adequate anesthesia on IAN (17).

The aim of this study was to determine the prevalence of $\mathrm{BMC}$ variations following the Langlais's et al. classification (10), by analyzing digital panoramic radiographs taken at the University Hospital Dubrava, Zagreb, Croatia.

\section{Materials and methods}

A retrospective study was carried out that included 1008 randomly selected digital panoramic radiographs taken from the University Hospital Dubrava database, in Zagreb. All radiographs were taken between January 2019 and August 2020.

Patients of both genders, older than 18 years of age were included in this study. Apart from a person's age, the exclusion dibularnoga kanala (16). Nadalje, dvostruki mandibularni kanali često su povezani s neuspjelom anestezijom donjega alveolarnoga živca (17).

Cilj ovoga istraživanja bio je odrediti učestalost varijacija DMK-a prema klasifikaciji Langlaisa i suradnika (10) analiziranjem digitalnih ortopantomogramskih snimki učinjenih u Kliničkoj bolnici Dubrava u Zagrebu.

\section{Materijali i metode}

Provedena je retrospektivna analiza 1008 nasumično odabranih digitalnih ortopantomogramskih snimki pohranjenih u arhivskoj bazi Kliničke bolnice Dubrava. Sve odabrane radiološke snimke učinjene su između siječnja 2019. i kolovoza 2020. godine.

U istraživanje su bili uključeni punoljetni pacijenti obaju spolova. Isključujući kriterij, osim godina, bili su ortopan- 
criteria included a low-quality panoramic radiograph. Digital panoramic radiographs were obtained using the Ortopantomograph Soredex (Nahkelantie 160, Tuusula, Finland), adjusted at $66 \mathrm{kVp}, 8.0 \mathrm{~mA}$, and acquisition time of $16.4 \mathrm{~s}$. All of the radiographs were projected and analyzed on a monitor screen by four experienced clinicians. The identification of $\mathrm{BMC}$ was confirmed if two radiolucent lines were present in the area of IAN, if at least 3 radiopaque borders were clearly visible on the panoramic radiograph and if the research team (one dentist and three oral surgeons) agreed with the finding. According to the criteria set by Langlais et al., BMCs were classified into four different types (Figure 1-4) (10).

Categorical data are shown by frequency and relative frequency and compared using the $\chi^{2}$ test. Data were collected and stored in the database in MS Excel. Statistical data processing was done using the MedCalc ver. 16. 2. 1. (MedCalc Software, Ostend, Belgium). The level of statistical significance was set at $5 \%(P<0.05)$.

\section{Results}

The total prevalence of BMC was $4.66 \%(n=47)$. As expected, there were more single mandibular canals registered than BMCs $\left(\chi^{2}=22.183, P<0.0001\right)$. No significant difference was found between male and female patients $\left(\chi^{2}=0.736\right.$, $P=0.947)$ although more BMCs were detected among the male population $(76.60 \%$ of the total BMCs identified) (Table 1). No statistically significant differences were found between the types of BMCs $\left(\chi^{2}=6.979, P=0.137\right)$ (Table 2). Type 4 BMC according to Langlais et al. was not registered in this study. In addition, we identified two new types that are not described in the Langlais et al. classification. We named them type 5 and type 6 (Figure 5-6) BMC. The description of BMC types is presented in Table 3.

The prevalence of BMC types is presented in Table 2 . Type 2 BMC was the most common BMC type, followed by type 5 and type 1 . The unilateral BMC $(63.8 \%, \mathrm{~N}=30)$ was more common than the bilateral BMC $(36.2 \%, \mathrm{~N}=17)$. tomogrami loše kvalitete. Digitalne ortopantomogramske snimke napravljene su uređajem Ortopantomograph Soredex (Nahkelantie 160, Tuusula, Finska), podešenim na $66 \mathrm{kVp}$, $8,0 \mathrm{~mA}, \mathrm{~s}$ vremenom akvizicije od 16,4 s. Svi ortopantomogrami prikazani su i analiziralo ih je četvero iskusnih kliničara. DMK je identificiran na panoramskim snimkama ako su bile vidljive dvije radiolucentne linije u području donjega alveolarnoga živca i najmanje tri jasno vidljive radioopaktne linije te ako se istraživački tim složio s time (tri oralna kirurga i jedan stomatolog). Prema kriterijima klasifikacije Langlaisa i suradnika (10) dvostruki mandibualrni kanali podijeljeni su u četiri različita tipa (slike 1. - 4.).

Kategorijski podatci prikazani su prema učestalosti i relativnoj frekvenciji te se uspoređuju s pomoću testa $\chi 2$. Podatci su prikupljeni i pohranjeni u bazu podataka u MS Excelu. Statistička obrada podataka obavljena je u MedCalc ver. 16. 2. 1. (MedCalc Software, Ostend, Belgija). Razina statističke značajnosti postavljena je na $5 \%(\mathrm{P}<0,05)$.

\section{Rezultati}

Ukupna učestalost DMK-a bila je 4,66 \% ( $\mathrm{n}=47)$. Očekivano, bilo je registrirano više pojedinačnih kanala u donjoj čeljusti od DMK-a $(\chi 2=22,183, \mathrm{P}<0,0001)$. Nije pronađena značajna razlika između pacijenata i pacijentica $(\chi 2=$ $0,736, P=0,947)$, iako je među muškom populacijom otkriveno više dvostrukih mandibularnih kanala (76,60 \% od ukupnoga broja identificiranih DMK-a) (tablica 1.). Nisu pronadene statistički značajne razlike između tipova DMK-a $(\chi 2=$ $6,979, \mathrm{P}=0,137)$ (tablica 2.). U ovom istraživanju nismo zabilježili DMK tipa 4 prema Langlaisu i suradnicima (10). Uz to, identificirali smo dva nova tipa koji nisu opisani u klasifikaciji Langlaisa i suradnika (10). Nazvali smo ih tip 5 i tip 6 DMK (slika 5-6). Opis tipova DMK-a nalazi se u tablici 3.

Učestalost DMK-a prikazana je u tablici 2. Tip 2 bio je najčešći, a zatim slijede tip 5 i tip 1 . Unilateralni DMK $(63,8$ $\%, \mathrm{~N}=30)$ bio je češći od bilateralnoga $(36,2 \%, \mathrm{~N}=17)$.

Table 1 Prevalence of bifid mandibular canal by gender

Tablica 1. Učestalost dvostrukoga mandibularnoga kanala prema spolu

\begin{tabular}{l|c|c|c} 
& $\begin{array}{c}\text { Total sample } \bullet \\
\text { Ukupno uzoraka }\end{array}$ & Male $\bullet$ Muškarci & Female $\bullet$ Žene \\
\hline Total number of x-rays $\bullet$ Ukupni broj ortopantomograma & 1008 & 596 & 412 \\
\hline Bifid mandibular canal (N, \%) $\bullet$ Dvostruki mandibularni kanal (N, \%) & $47(4.66)$ & $36(6.04)$ & $11(2.67)$ \\
\hline Statistics $\bullet$ Statistika & $\chi^{2}=0.736 ; P=0.947$ & & \\
\hline
\end{tabular}

Table 2 Prevalence of different types of bifid mandibular canals

Tablica 2. Učestalost različitih tipova dvostrukih mandibularnih kanala

\begin{tabular}{|c|c|c|c|c|c|}
\hline & Total • Ukupno & Female $\bullet \check{Z ̆ e n e}_{\text {en }}$ & Male • Muškarci & $\begin{array}{l}\text { Unilateral • } \\
\text { Unilateralno }\end{array}$ & Bilateral $\bullet$ Bilateralno \\
\hline Type $1 \bullet$ Tip 1 & $8(17.02 \%)$ & 2 & 6 & 8 & 0 \\
\hline Type $2 \cdot \operatorname{Tip} 2$ & $21(44.68 \%)$ & 4 & 17 & 11 & 10 \\
\hline Type $3 \bullet$ Tip 3 & $3(6.38 \%)$ & 1 & 2 & 0 & 3 \\
\hline Type $4 \cdot$ Tip 4 & $0(0.00 \%)$ & 0 & 0 & 0 & 0 \\
\hline Type $5 \bullet$ Tip 5 & $9(19.15 \%)$ & 2 & 7 & 7 & 2 \\
\hline \multirow[t]{2}{*}{ Type $6 \bullet$ Tip 6} & $6(12.77 \%)$ & 2 & 4 & 4 & 2 \\
\hline & 47 & $11(23.4 \%)$ & $36(76.6 \%)$ & $30(63.8 \%)$ & $17(36.2 \%)$ \\
\hline
\end{tabular}




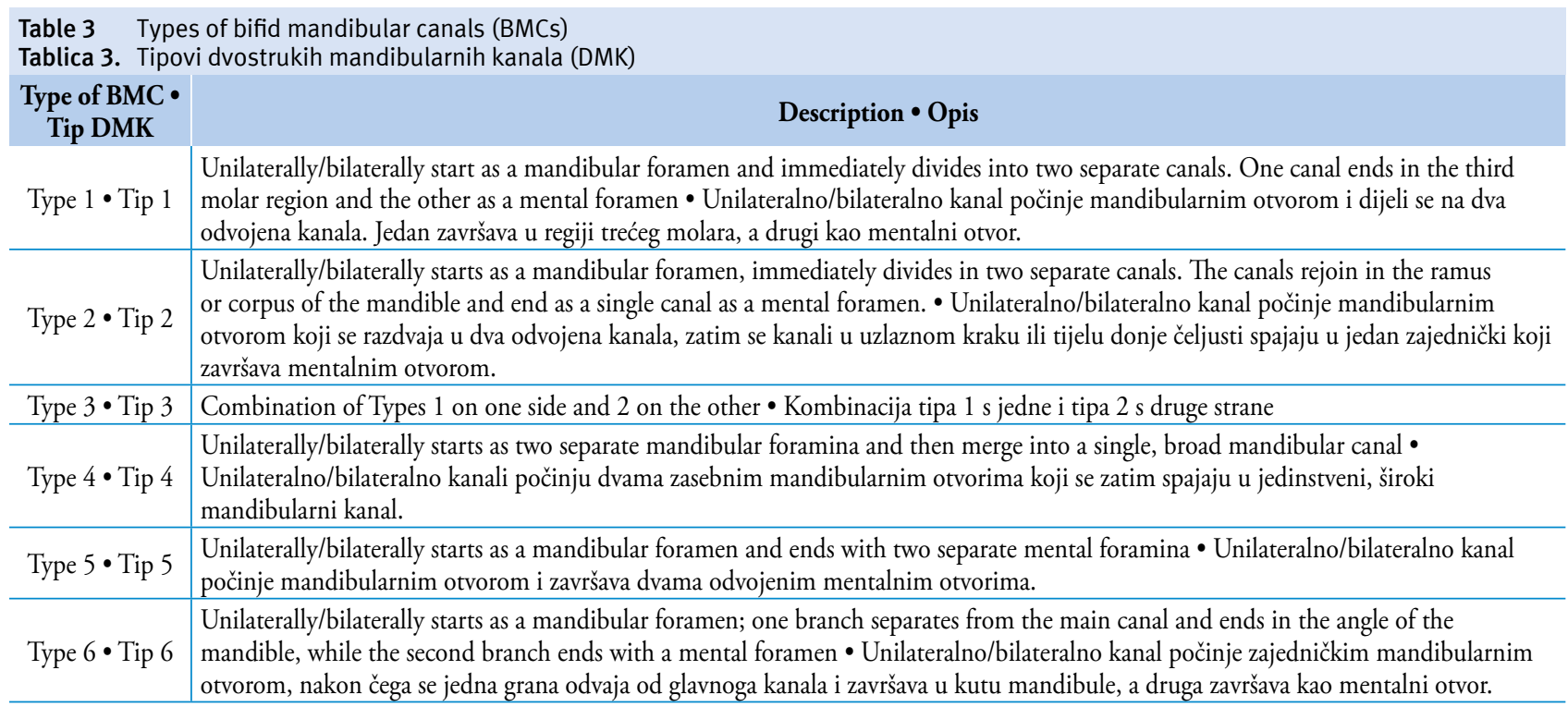

\section{Discussion}

Knowledge of the head and jaws anatomy is an imperative in dentistry (18). The bifid mandibular canal is one of the most common anatomical variations of the mandibular canal although it is usually ignored and misdiagnosed in dental practice (19). Although panoramic radiographs are commonly used as a preoperative examination tool for dental and oral surgical procedures, they have limitations in detecting some uncommon anatomical and morphological $\mathrm{BMC}$ variations. This study revealed a prevalence of $4.66 \%$, which is comparable to several studies on the topic $(14,16,19)$, however the reported prevalence in the available literature varies from 0.08 to $8.3 \%$, depending on the used radiological diagnostic tool $(7-10,20-25)$. The prevalence of $4.66 \%$ in this study is much higher than the prevalence of $0.35 \%$ reported by Sanchis et al. (21), 0.9\% reported by Nortje et al. (7) and the prevalence of $0.95 \%$ reported by Langlais et al (10). These differences in values may be explained by the quality of the examination technique used to detect BMC and the observers' experience. The studies that reported low prevalence of BMCs (less than 1\%), used conventional panoramic radiographs. Digital radiographs, which were used as a diagnostic tool in this study, definitely enabled better precision and clarity of the image $(7,10,20)$. The studies that reported a prevalence similar to the one obtained in this study, also used digital radiographs, e.g. study by Haas et al. (16), Schilling et al. (23) and Andrade et al. (14) who reported the prevalence of $4.2 \%, 5.0 \%$ and $5.3 \%$, respectively. However, the studies with $\mathrm{CBCT}$ imaging and BMC identification showed a much higher prevalence (from 10 to 65\%) (7-10). The utilization of digital panoramic radiographs in order to detect BMCs has some objective disadvantages compared to CBCT scans. However, by using the most commonly used diagnostic tool in dentistry, we aimed to assess the possibilities of diagnosing BMCs on digital panoramic radiographs.

No statistically significant difference was found between males and females and BMC prevalence in this and several other studies with a sample size ranging from several hundred

\section{Rasprava}

Poznavanje anatomije glave i čeljusti veoma je važno u dentalnoj medicini (18). Dvostruki mandibularni kanal jedna je od najčešćih anatomskih varijacija mandibularnoga kanala, premda se u svakodnevnoj praksi često zanemaruje i pogrešno dijagnosticira (19). Iako su ortopantomogramske snimke najčešći alat prije dentalnih i oralno-kirurških zahvata, imaju određena ograničenja u detektiranju nekih neuobičajenih anatomskih i morfoloških varijacija DMK-a. U ovom istraživanju utvrdili smo učestalost DMK-a od 4,66 $\%$, što se može usporediti s rezultatima nekoliko sličnih studija $(14,16,19)$, no objavljena učestalost u dostupnoj literaturi varira od 0,08 do $8,3 \%$, ovisno o vrsti analiziranih radioloških dijagnostičkih snimki $(7-10,20-25)$. Učestalost od 4,66 \% u ovom istraživanju dosta je viša od učestalosti od 0,35 \% o kojoj su izvijestili Sanchis i suradnici (21), $0,9 \%$ o čemu su izvijestili Nortje i suradnici (7) te učestalosti od $0,95 \%$ koju su objavili Langlais i suradnici (10). Te razlike u vrijednostima mogu se objasniti kvalitetom tehnike snimanja koja se koristi za otkrivanje DMKa i iskustvom promatrača. Studije koje su izvijestile o nižoj učestalosti DMK-a (manje od $1 \%)$ koristile su se konvencionalnim ortopantomogramima. Digitalni ortopantomogrami, koji su korišteni kao dijagnostički alat u ovom istraživanju, sigurno su omogućili veću preciznost i jasnoću slike (7, 10, 20). Studije u kojima su autori izvijestili o učestalosti sličnoj onoj u ovom istraživanju, također su se koristili digitalnim ortopantomogramima, na primjer Haas i suradnici (16), Schilling i suradnici (23) i Andrade i suradnici (14) koji su izvijestili o učestalosti od 4,2 \%, 5,0 \% i 5,3\%, retrospektivno. No istraživanja provedena na temelju CBCT snimki pokazuju mnogo veću učestalost DMK-a (od 10 do $65 \%)(7-10)$. Korištenje digitalnih ortopantomograma za otkrivanje DMK-a ima objektivne nedostatke u usporedbi s CBCT snimanjem, no kako je to najčešće korišten dijagnostički alat u dentalnoj medicini, nastojali smo procijeniti mogućnosti dijagnosticiranja DMK-a na digitalnim ortopantomogramima. 
up to several thousand examined panoramic radiographs (2428).

Types 1 and 2, according to Langlais et al. classification (10), were the most common BMC type in several studies. Fuentes et al. (24) in Chilean, Kuczynski et al. (25) and Correr et al. (20) in Brazilian population reported that the most prevalent variation in their studies was type 1 (67\%, 83\% and $72.6 \%$, respectively) $(20,24,25)$. Type 2 was the most prevalent variation of BMC in this study (44.68\%); furthermore, type 2 was also most frequent in a study by Langlais et al. (10) (USA) (54\%) and in the study by Kalantar Motamendi et al. (9) (Iran) (82\%). With respect to the abovementioned studies, it should be noted that, apart from the differences in sample size, ethnical diversity may affect the results. Overall, the results obtained in this study resembled those of Langlais et al. (10) who studied the North American population (44.68 and 54\%).

Our study revealed two types of BMCs not described in the BMC classifications available in the literature. We named them type 5 and type 6 . Type 5 was referred to as unilateral or bilateral BMC that started from the mandibular foramen and ended with two separate mental foramina. Mahnaz et al. (29) published the case of a 47-year-old male patient who had experienced a persistent dull pain after the root canal treatment. He observed two separate mandibular foramina and canals, which merged into a single canal anteriorly and ended as a single mental foramen on the right side (type 4 according to Langlais et al. (10) classification). On the left side, he observed two separate mandibular foramina and canals which ended as two separate mental foramina, which corresponds to the type 5 described in this study. Along with the type 1 and 2 , type 5 was also not uncommon ( $=9 ; 0.89 \%)$.

Type 6 referred to as unilateral or bilateral canal that started from the common mandibular foramen, after which one branch separates from the main canal and ends in the angle of the mandible, while the second branch ends a mental foramen. To the best of our knowledge, type 6 was not previously described in the literature. We have not registered type $4 \mathrm{BMC}$ in our study. Kuczynski et al. also did not register type $4 \mathrm{BMC}$ in their study on 3024 panoramic radiographs (25). An extremely rare anatomical variation of a trifid mandibular canal was not observed in this study. Data on trifid mandibular canals are limited to several case reports $(30,31)$.

Accessory canals have been implicated in failure to achieve complete anesthesia since 1960, when variations of mandibular canal were identified (32). Based on the available literature, a success rate of the IAN block anesthesia has ranged from $80-92 \%$. Kaufman et al. have registered a success rate of the IAN block ranging from 80 to $85 \%$, while Keetley and Moles recorded a higher success rate of $91.9 \%$, which was lower than other nerve blocks in the maxilla (33, 34). There are several possibilities for the ineffectiveness of IAN blocks, such as the presence of an acute infection, poor technique and the presence of a morphological and anatomical variation (35-37). Lew and Townsen (17) discussed the failure of obtaining an adequate anesthesia in their case report due to a BMC with two separate mandibular foramina, i.e. the type $4 \mathrm{BMC}$ according to Langlais et al. classification
Nije pronađena statistički značajna razlika između muškaraca i žena i učestalosti DMK-a u ovoj studiji i u nekoliko drugih $s$ veličinom uzorka od nekoliko stotina do nekoliko tisuća pregledanih ortopantomogramskih snimki $(24-28)$.

Tipovi 1 i 2, prema klasifikaciji Langlaisa i suradnika (10), bili su najčešći tipovi DMK-a u nekoliko istraživanja. Fuentes i suradnici (24) u čileanskoj populaciji, Kuczynski i suradnici (25) te Correr i suradnici (20) u brazilskoj populaciji izvijestili su da je najčešća varijacija u njihovim istraživanjima bio tip 1 (67 \%, $83 \%$ i 72,6\%, retrospektivno). Tip 2 bio je najčešća varijacija DMK-a u ovom istraživanju (44,68 \%). Nadalje, tip 2 je također bio najčešći u istraživanju Langlaisa i suradnika (10) (SAD) (54\%) i u istraživanju Kalantara Motamendija i suradnika (9) (Iran) (82 \%). S obzirom na spomenuta istraživanja valja napomenuti da, osim razlika u veličini uzorka, na rezultate može utjecati i etnička raznolikost. Sveukupno, rezultati dobiveni u ovoj studiji najsličniji su rezultatima istraživanja Langlaisa i surdnika (10) koji su analizirali sjevernoameričko stanovništvo (44,68 i 54 \%).

Ovo istraživanje otkrilo je dva nova tipa DMK-a koji dosad nisu opisani u dostupnoj literaturi i nazvali smo ih tip $5 \mathrm{i}$ tip 6. Tip 5 odnosi se na unilateralni ili bilateralni DMK koji počinje mandibularnim otvorom i završava s dvama odvojenim mentalnim otvorima. Mahnaz i suradnici (29) objavili su prikaz slučaja 47-godišnjaka koji je nakon liječenja korijenskoga kanala trajno osjećao tupu bol. Na desnoj strani uočio je dva odvojena mandibularna otvora i kanala koji se spajaju u jedan i završavaju kao jedan mentalni otvor (odgovara tipu 4 prema klasifikaciji Langlaisa i suradnika) (10)). Na lijevoj strani uočio je dva odvojena mandibularna otvora koji završavaju kao dva odvojena mentalna otvora, što odgovara tipu 5 iz našega istraživanja. Uz tip 1 i 2 , tip 5 također nije bio neuobičajen $(\mathrm{N}=9 ; 0,89 \%)$.

Tip 6 odnosi se na unilateralni ili bilateralni DMK koji počinje zajedničkim mandibularnim otvorom nakon čega se jedna grana odvaja od glavnoga kanala i završava u kutu mandibule, a druga završava kao mentalni otvor. Koliko znamo, tip 6 nije do sada bio opisan u dostupnoj literaturi. U našem istraživanju nismo registrirali DMK tip 4. Kuczynski i suradnici također nisu zabilježili DMK tip 4 u svojoj studiji na temelju 3024 ortopantomograma (25). Unutar istraživanja nije uočena iznimno rijetka anatomska varijacija trostrukoga mandibularnoga kanala. Podatci o trostrukim mandibularnim kanalima ograničeni su na nekoliko prikaza slučajeva $(30,31)$.

Akcesorni kanali povezivani su s neuspjelom anestezijom 1960. godine kada su otkrivene varijacije mandibularnoga kanala (32). Na temelju dostupne literature, uspješnost anestezije donjega alveolarnoga živca kreće se od 80 do $92 \%$. Kaufman i suradnici zabilježili su stopu uspješnosti anestezije donjega alveolarnoga živca u rasponu od 80 do $85 \%$, a Keetley i Moles višu od $91,9 \%$, što je niže od ostalih anestezija u maksili $(33,34)$. Nekoliko je mogućih razloga za neučinkovitost anestezije donjega alveolarnoga živca, poput akutne infekcije, loše tehnike ubrizgavanja i morfoloških i anatomskih varijacija $(35-37)$. Lew i Townsen (17) raspravljali su o neuspjelim anestezijama u svojem prikazu slučaja zbog DMK-a s dvama odvojenim mandibularnim otvorima, tj. o DMK-u ti- 
(10). Apart from the type 4, all other BMC types could present an obstacle for an effective IAN block $(32,38)$. Based on the findings of this and similar studies, it would be interesting to assess the connection between the anatomical variation of BMC and the efficiency of IAN blocks.

Types 1 and 2 by Langlais et al. (10) and type 5 described in this study, probably have the highest risk of IAN injury during tooth extraction, dental implant placement, apicoectomy or removal of pathologies in the molar region. The reported frequency of IAN injuries associated with extraction of third molar ranges from $0.4-9.4 \%$, but the risk of permanent IAN injury was reported, which was less than $1 \%$ (3942). Moreover, types 1, 2 and 5 were the most common types in our study. De Toledo Telles-Araújo et al. (42) did not find CBCT superior to panoramic radiograph in avoiding nerve injuries i.e. neurosensory disturbances following the removal of the mandibular third molar.

\section{Conclusions}

This study revealed a relatively high prevalence rate of BMCs. No significant difference was found between males and females with BMC. Type $2 \mathrm{BMC}$, according to Langlais et al. classification (10), was the most common BMC type. We identified and described two new BMC types, Type 5 and Type 6, previously not described in the available literature. The results obtained in this study point to the importance of a thorough radiological planning prior to surgical interventions in the mandible in order to avoid potential complications.

\section{Conflict of Interest}

None declared.

Author's Contribution: A.M., I.S., D.M. - conceptualized, wrote and made the study design; H.M. and K.M. participated in the acquisition of data; P.Đ., Ž.O., I.Z. and D.B. participated in data analysis and interpretation of data. All of the authors substantially contributed to drafting of the article, critical revision and gave their final approval of the version to be submitted. pa 4 prema klasifikaciji Langlaisa i suradnika (10). Osim tipa 4, svi drugi tipovi DMK-a mogli bi biti prepreka za učinkovitu anesteziju donjega alveolarnoga živca $(32,38)$. Na temelju nalaza u ovoj i sličnim studijama, bilo bi zanimljivo procijeniti vezu između anatomske varijacije DMK-a i učinkovitosti anestezije donjega alveolarnoga živca.

Tipovi 1 i 2 prema Langlaisu i suradnicima (10) i tip 5 opisan u ovom istraživanju vjerojatno imaju najveći rizik od ozljede donjega alveolarnoga živca tijekom vađenja zuba, ugradnje dentalnoga implantata, apikotomije ili uklanjanja patoloških tvorbi u molarnoj regiji. Učestalost ozljeda donjega alveolarnoga živca povezanih s ekstrakcijom trećega molara kreće se od 0,4 do 9,4\%, ali je rizik od trajne ozljede živca manji od $1 \%(39-42)$. Štoviše, tipovi 1, 2 i 5 bili su najččšci u našem istraživanju. De Toledo Telles-Araújo i suradnici (42) nisu pronašli da je CBCT superiorniji u odnosu prema ortopantomogramu u izbjegavanju ozljeda živaca, tj. neurosenzoričnih tegoba nakon uklanjanja donjega trećega kutnjaka.

\section{Zaključak}

U ovom istraživanju otkrivena je razmjerno visoka učestalost DMK-a. Nije pronađena značajna razlika između muškaraca i žena s DMK-om. DMK tip 2 prema klasifikaciji Langlaisa i suradnika (10) bio je najčešći. Identificirali smo i opisali dva nova tipa DMK-a - tip 5 i tip 6 koji prije nisu opisani u dostupnoj literaturi. Ti rezultati pokazuju važnost temeljitoga radiološkog planiranja prije kirurških intervencija u donjoj čeljusti kako bi se izbjegle moguće komplikacije.

\section{Sukob interesa}

Autori nisu bili u sukobu interesa.

Autorski doprinos: A. M., I. S., D. M. - osmislili su, napisali i izradili dizajn studije; H. M. i K. M. - sudjelovali su u prikupljanju podataka. P. D., Ž. O., I. Z. i D. B. - sudjelovali su u analizi podataka i njihovu tumačenju. Svi autori znatno su pridonijeli izradi članka i kritičkoj reviziji te su dali svoje konačno odobrenje za objavljenu verziju.

\begin{abstract}
Sažetak
Dvostruki mandibularni kanal (DMK) anatomska je varijacija s učestalošću u rasponu od 0,08 do 65 $\%$. Njegovo uočavanje iznimno je važno kako bi se prevenirale moguće komplikacije tijekom oralnokirurških i drugih dentalnih zahvata. Svrha: Cilj istraživanja bio je ustanoviti morfološke klasifikacije i učestalost dvostrukoga mandibularnog kanala koristeći se ortopantomogramskim snimkama. Materijali i metode: Obavljena je retrospektivna analiza 1008 digitalnih ortopantomograma (412 od žena i 596 od muškaraca) kako bi se identificirao tip i učestalost DMK-a. Tri oralna kirurga i jedan stomatolog analizirali su ortopantomogramske snimke i dvostruki mandibularni kanal klasificirali su u šest različitih tipova - četiri prema Langlaisu i suradnicima (tipovi 14 ) i dva nova (tip 5 i 6) koje su opisali autori ovoga istraživanja. Rezultati : Učestalost DMK bila je 4,66 \% $(n=47)$, bez statistički značajne razlike prema spolovima $\left(P=0,947 ; \chi^{2}=0,74\right)$. Učestalost tipa 1 iznosila je $0,79 \%(n=8)$, tipa 2 bila je $2,08 \%(n=21)$, tipa $3-0,30 \%(n=3)$, tipa $4-0 \%(n=0)$, tipa $5-0,89 \%(n=9)$ i tipa $6-0,60 \%$ $(n=6)$. Zaključak: U ovom istraživanju utvrdili smo razmjerno visoku učestalost DMK-a među stanovnicima Zagreba. Nadalje, opisana su i dva nova tipa. Rezultati istraživanja pokazuju koliko je važna temeljita i temeljita analiza ortopantomograma prije svakoga invazivnog zahvata na donjoj čeljusti.
\end{abstract}

Zaprimljen: 16. srpnja 2021. Prihvaćen: 1. rujna 2021.

Adresa za dopisivanje Ivan Salarić Sveučilište u Zagrebu Stomatološki fakultet Klinika za kirurgiju lica, čeljusti i usta Klinička bolnica Dubrava Av. G. Šuška 6, 10000 Zagreb salaric@sfzg.hr

MeSH pojmovi: donja čeljust; anatomske varijacije; oralna kirurgija Ključne riječi: radiografija, ortopantomogram, anatomska varijacija, mandibula, mandibularni živac, mandibularni kanal, dvostruki mandibularni kanal 


\section{References}

1. Patterson JE, Funke FW. Bifid inferior alveolar canal. Oral Surg. 1973;36:287-8

2. Kirsch TA, Jordan JE. Duplication of the mandibular canal. Oral Surg Oral Med Oral Pathol. 1973; 35(1):133-4.

3. Kieser J, Kieser D, Hauman T. The course and distribution of the inferior alveolar nerve in the edentulous mandible. I Craniofac Surg. 2005;16(1):6-9.

4. Naitoh M, Hiraiwa Y, Aimiya H, Ariji E. Observation of bifid mandibular canal using cone-beam computerized tomography. Int J Oral Maxillofac Implants. 2009;24:155-9.

5. Chavez-Lomeli M E, Lory J M, Pompa J A, Kjaer I: The human mandibular canal arises from three separate canals innervating different tooth groups. J Dent Res. 1996;75:1540-4.

6. Von Arx T, Bornstein MM. The bifid mandibular canal in three-dimensional radiography: morphologic and quantitative characteristics. Swiss Dent J. 2021;131(1):10-28.

7. Nortje CJ, Farman AG, Grotepass FW. Variations in the normal anatomy of the inferior dental canal: a retrospective study of the panoramic radiographs from 3612 routine dental patients. $\mathrm{Br}$ J Oral Surg. 1977;15:55-63.

8. Durst JH, Snow JE. Multiple mandibular canals: oddities or fairly common anomalies? Oral Surg Oral Med Oral Pathol. 1980;49:272-3.

9. Kalantar Motamendi MH, Navi F, Serabi N. Bifid mandibular canals: prevalence and implications. J Oral Maxillofac Surg. 2015;73:387-90.

10. Langlais RP, Broadus R, Glass BJ. Bifid mandibular canals in panoramic radiographs. J Am Dent Assoc. 1985;110:923-26.

11. Aps JKM. Number of accessory or nutrient canals in the human mandible. Clin Oral Investig. 2014;18(2):671-6.

12. Kuribayashi A, Watanabe H, Imaizumi A, Tantanapornkul W, Katakami K, Kurabayashi T. Bifid mandibular canals: cone beam computed tomography evaluation. Dentomaxillofac Radiol. 2010;39(4):235-9.

13. Rashid SA, Ali J, Al-Nakib L. Identification of bifid mandibular canals among Iraqi subjects using panoramic imaging system. J Bagh College Dentistry. 2011;23:76-80.

14. Andrade YDN, Araujo EBJ, Souza LMA, Gropppo FC. Analysis of anatomical variations of the mandibular canal found on panoramic radiographs. Rev Odontol UNESP. 2015; 44(1):31-6.

15. Castro MAA, Amaral TMP, Abreu MHG, Mesquita RA. Classifications of mandibular canal branching: A review of literature. World I Radiol. 2015;7(12):531-7.

16. Haas LF, Dutra K, Porporati AL et al. Anatomical variations of mandibular canal detected by panoramic radiography and CT: a systematic review and meta-analysis. Dentomaxillofac Radiol. 2016;45(2):20150310.

17. Lew K, Townsen G. Failure to obtain adequate anaesthesia associated with a bifid mandibular canal: a case report. Aust Dent J. 2006;51(1):86-90.

18. Dietrichkeit Pereira JG, Fróes Lima K, Alves da Silva RH. Mandibular Measurements for Sex and Age Estimation in Brazilian Sampling. Acta Stomatol Croat. 2020;54(3):294-301.

19. Capote TS, Goncalves Md, Campos JA. Retromoral canal associated with age, sex, bifid mandibular canal, and accessory mental foramen in panoramic radiographs of Brasilians. Anat Res Int. 2015;2015:434083.

20. Correr GM, Iwanko DL, Piotto D, Ulbrich LM, Araujo MR, Deliberador, TM. Classification of bifid mandibular canals using cone beam computed tomography. Braz Oral Res. 2013;27(6):510-6.

21. Sanchis JM, Penarrocha M, Soler F. Bifid mandibular canal. J Oral Maxillofac Surg. 2003;61(4):422-4.

22. Rothe TM, Kumar P, Shah N, Venkatesh R, Vassandacoumara V, Mahajan A. Prevalence of Bifid Mandibular Canal Amongst In- dian Population: A Radiographic Study. J Maxillofac Oral Surg. 2018;17(3):379-82.

23. Schilling LJ, Schilling QA, San Pedro VJ. Mandibular canal duplication prevalence, digital panoramic radiography analysis. Int J Odontostomat.2010; 4(3):207-13

24. Fuentes A, Arias C, Farfán N, et al. Morphological variations of the mandibular canal in digital panoramic radiographs: a retrospec tive study in a Chilean population. Folia Morphol. 2019;78(1):163 70.

25. Kuczynski A, Kucharski W, Franco A. Prevalence of bifid mandibular canals in panoramic radiographs: a maxillofacial surgical scope. Surg Radiol Anat. 2014; 36(9):847-50.

26. Castro MAA, Barra SG, Vich MOL, Abreu MHG, Mesquita RA. Mandibular canal branching assessed with cone beam computed tomography. Radiol Med. 2018;123(8):601-8.

27. Yang X, Lyu C, Zou D. Bifid Mandibular Canals Incidence and Anatomical Variations in the Population of Shanghai Area by Cone Beam Computed Tomography. J Comput Assist Tomogr. 2017;41(4):535-40.

28. Sonneveld KA, Mai PT, Hogge M, Choi EY, Portnof JE. Bifid Mandibular Canal: A Case Review and Retrospective Review of CBCTs. Implant Dent. 2018;27(6):682-6.

29. Mahnaz S, Badrian H, Ghorbanizadeh S. Bilateral bifid mandibular canal. Dent Res J. 2012;(12):132-5.

30. Rashsuren O, Choi JW, Han WJ, Kim WK. Assessment of bifid and trifid mandibular canals using cone-beam computed tomography. Imag Sci in Dent. 2014:44:229-36.

31. Auluck A, Pai KM, Mupparapu M. Multiple mandibular nerve canals: radiographic observations and clinical relevance. Quintessence Int. 2007;38(9):781-7.

32. Ngeow WC, Chai W-L. The clinical anatomy of accessory mandibular canal in dentistry. Clin Anat. 2020;33(8):1214-27.

33. Keetely A, Moles DR. A clinical audit into the success rate of inferior alveolar nerve block anaesthesia in general dental practice. Prim Dent Care. 2001;8:139-42.

34. Kaufman E, Weinstein P, Milgrom P. Difficulties in achieving local anaesthesia. J Am Dent Assoc. 1984;108:205-8.

35. Meechan JG, Robb ND, Seymour RA. Pain and anxiety control for the conscious dental patient. Oxford: Oxford University Press; 1998. p.151-7.

36. De Santis JL, Liebow C. Four common mandibular nerve anomalies that lead to local anaesthesia failures. J Am Dent Assoc. 1996;127:1081-6.

37. Brito NMdSO, Soares RdSC, Monteiro ELT, Martins SCR, Cav alcante JR, Grempel RG et al. Additive Manufacturing for Surgical Planning of Mandibular Fracture. Acta Stomatol Croat. 2016;50(4):348-53.

38. Meechan JG. Supplementary routes to local anaesthesia. Int Endod J. 2002; 36:885-96.

39. Céspedes-Sánchez JM, Ayuso-Montero R, Marí-Roig A, ArranzObispo C, López-López J. The importance of a good evaluation in order to prevent oral nerve injuries: a review. Acta Odontol Scand. 2014; 72(3):161-7.

40. Pippi R, Spota A, Santoro M. Prevention of Lingual Nerve Injury in Third Molar Surgery: Literature Review. J Oral Maxillofac Surg. 2017;75(5):890-900

41. Su N, van Wijk A, Berkhout E, et al. Predictive Value of Panoramic Radiography for Injury of Inferior Alveolar Nerve after Mandibular Third Molar Surgery. J Oral Maxillofac Surg. 2017;75(4):663-79.

42. de Toledo Telles-Araújo G, Peralta-Mamani M, Caminha RDG et al. CBCT does not reduce neurosensory disturbances after third molar removal compared to panoramic radiography: a systematic review and meta-analysis. Clin Oral Investig. 2020; 24(3):1137-49. 